\title{
PEMANFAATAN HASIL SAMPING PENGOLAHAN IKAN PEPEREK (Leiognathus equulus) MENJADI TEPUNG IKAN
}

\author{
Noviyanti Lunda *, Moh. Nuh Ibrahim, Suwarjoyowirayatno \\ Jurusan Teknologi Hasil Perikanan Fakultas Perikanan dan Ilmu Kelautan Universitas Halu Oleo, \\ Jalan H.E.A Mokodompit Kampus Bumi Tridharma Anduonohu, Kendari 93232 Sulawesi Tenggara \\ Telepon +6282343413025 \\ *Korespondensi: noviyantilunda015@gmail.com \\ Diterima: 8 Maret 2019/Disetujui: 2 April 2019
}

Cara sitasi: Lunda N, Ibrahim MN, Suwarjoyowirayatno. 2019. Pemanfaatan hasil samping pengolahan ikan peperek (Leiognathus equulus) menjadi tepung ikan. Jurnal Fish Protech. 2(1): 11-17.

\begin{abstract}
Abstrak
Penelitian ini bertujuan untuk mengetahui pengaruh perlakuan tulang, kepala dan jeroan terhadap uji organoleptik, uji proksimat dan uji mineral tepung ikan peperek. Penelitian ini menggunakan Rancangan Acak Lengkap (RAL) yang terdiri dari tiga perlakuan yaitu perlakuan A (tulang), perlakuan B (Kepala) dan perlakuan C (Jeroan) dan ulangan sebanyak empat kali. Kandungan kimia protein diuji dengan metode Spektofotometri, kadar karbohidrat diuji dengan metode karbohidrat total dan uji mineral kalsium diuji dengan metode peniteran subtitusi. Data hasil pengamatan dianalisa menggunakan ANOVA (Analysis of Variance) pada taraf 95\%, apabila terdapat beda nyata $(\mathrm{P}>0,05)$ maka dilakukan uji lanjut dengan uji DMRT (Duncan Multiple Range Test) pada taraf nyata $95 \%$. Hasil tertinggi untuk penilaian organoleptik meliputi kenampakan, bau dan tekstur terdapat pada perlakuan A, dimana memiliki nilai kenampakan 8,04, nilai bau 8,02 dan nilai tekstur 8,04. Hasil tertinggi pada uji proksimat meliputi kadar protein yaitu $31,51 \%$ dan kadar karbohidrat yaitu $0,032 \%$ dan nilai tertinggi untuk uji mineral meliputi kadar kalsium terdapat pada perlakuan A yaitu 0,54\%.
\end{abstract}

Kata Kunci: Tepung ikan, kepala, tulang, jeroan, ikan peperek

\section{THE UTILIZATION OF PROCESSING BY PRODUCT OF PEPEREK FISH (Leiognathus equulus) INTO FISH MEAL}

\begin{abstract}
This study aims to determine the effect of differences raw material (head, bone and viscera) onorganoleptic test, proximate analysis and calcium of peperek fish meal. This study use dacompletely randomized design (CRD) consisting of three treatments, A (bone), B (head) and C (Viscera) and four time replication. Observational data were analyzed using ANOVA (Analysis of Varience) at the level of 95\% (P>0,05), and continued with DMRT test (Duncan Multiple Range Test). There sult of this study for organoleptic test such as appearance, odor and texture were 8,04, 8,02, 8,04 respectively. Proximate analysis such as protein and carbohidrat were $31,51 \%$ and $0,032 \%$ respctively. The highest value of calcium content is $0,54 \%$.
\end{abstract}

Key woard:, fiSh meal, bone, head, viscera, pererek fish 


\section{PENDAHULUAN}

Ikan peperek merupakan ikan demersal yang menjadi salah satu penyusun komunitas ikan di perairan Teluk Kendari (Asriyana et al., 2009). Ikan ini termasuk dalam famili Leiognathidae memiliki nilai yang cukup ekonomis sehingga nelayan cenderung mengeksploitasi sumber daya ini dalam jumlah yang besar. Jenis ikan ini merupakan ikan yang hidup di dasar perairan hingga mencapai permukaan (benthopelagik) sebagian besar hidup di laut dan beberapa di air payau.

Umumnya ikan memiliki kadar air yang tinggi demikian pula ikan peperek yang mengandung $77,07 \%$ kadar air (Nugroho, 2006). Tingginya kadar air yang terkandung dalam tubuh ikan, merupakan media yang baik untuk pertumbuhan mikroba, hal ini menunjukkan produk perikanan mudah sekali busuk, karena itu dilakukan pengolahan dan pengawetan. Pengolahan ikan peperek biasanya banyak menghasilkan hasil samping atau limbah, namun hasil samping tersebut tidak dimanfaatkan. Untuk meningkatkan nilai ekonomis dari hasil samping pengolahan ikan peperek salah satunya adalah dapat diolah menjadi tepung ikan. Hasil samping tersebut masih mengandung sejumlah protein dan kalsium yang dapat dimanfaatkan, sehingga dalam penelitian ini dapat memanfaatkan hasil samping pengolahan ikan peperek seperti tulang, kepala dan jeroan menjadi tepung ikan.

Tepung ikan merupakan salah satu bentuk pemanfaatan hasil samping (limbah) pengolahan utama ikan maupun dari hasil tangkapan sampingan. Tepung ikan merupakan salah satu hasilpengawetan ikan dalam bentuk kering (Ilyas, 1982). Tepung ikan pangan merupakan bahan makanan yang kaya akan protein sehingga dapat digunakan untuk tujuan makanan diet, maupun suplemen. Tepung ikan pangan yang berbau khas dapat ditambahkan pada sop atau makanan yang direbus, sebagai flavour pada roti, juga sebagai bahan aditif pada produk roti tawar (Burgess et al., 1967). Menurut Murtidjo (2001), tepung ikan merupakan bahan baku makanan ternak dan ikan yang bersih dan kering, yang dibuat dari jaringan tubuh ikan, baik seutuhnya, dicampur ataupun tidak dengan sisa prosesing ikan, dan jaringan tersebut belum membusuk. Proses pengolahannya dengan atau tanpa diekstraksi sebagian minyaknya.

Kandungan gizi tepung ikan tergantung dari jenis ikan yang digunakan sebagai bahan bakunya. Tepung ikan yang berkualitas tinggi mengandung komponen-komponen antara lain air 6-10\%, lemak 5-12\%, protein $60-75 \%$, abu $10-20 \%$ (Hidayat et al., 2006).

\section{BAHAN DAN METODE}

\section{Bahan dan Alat}

Bahan yang digunakan yaitu tulang kepala ikan peperek, tulang punggung ikan peperek, jeroan ikan peperek yang diperoleh dari hasil samping pembuatan kerupuk amplang.

\section{Pembuatan Tepung Ikan Peperek}

Proses pengolahan dimulai dengan hasil samping pengolahan yaitu tulang, kepala dan jeroan ikan peperek dicuci sampai bersih, kemudian menimbang berat kepala, tulang dan jeroan ikan peperek. Pengukusan dilakukan dengan mengisi air kedalam panci, setelah itu menunggu air hingga mendidih, setelah mendidih tulang, kepala dan jeroan kemudian dimasukan kedalam panci dengan suhu $100{ }^{\circ} \mathrm{C}$ dengan lama waktu pengukusan selam 
30 menit. Penjemuran dilakukan secara alami dengan menggunakan sinar matahari. Tulang, kepala dan jeroan ikan peperek disusun di atas nampan secara rapi, agar keringnya dapat merata. Hasil samping tulang, kepala dan jeroan di jemur selama lima jam, mulai dari jam sembilan pagi sampai jam satu siang dalam satu hari. Tulang kepala, tulang punggung dan jeroan dikeringkan dibawah sinar matahari selama 3 hari hingga benar-benar kering. Untuk mendapatkan pengeringan yang merata, tulang, kepala dan jeroan dibalik setiap dua jam sekali. Penggilingan dilakukan dengan menggunakan blender. Tulang kepala, tulang punggung dan jeroan yang telah kering dipatah-patahkan, agar lebih mudah digiling menggunakan blender. Tulang, kepala, dan jeroan yang telah diblender kemudian diayak agar ampas kasarnya dapat terpisah. Tepung ikan yang telah jadi yang meliputi tepung tulang ikan, tepung kepala ikan dan tepung jeroan ikan dikemas dan diberi kode.

\section{Penilaian Organoleptik}

Penilaian organoleptik terhadap tepung ikan peperek yang meliputi Kenampakan, bau dan tekstur dengan menggunakan skala sensorik. Pengujian ini menggunakan 25 orang panelis.

\section{Analisis Proksimat Tepung Ikan Peperek}

Analisis proksimat tepung ikan peperek meliputi analisis kadar protein dengan metode spektofotometri dan analisis kadar karbohidrat dengan metode karbohidrat total (BPT, 2005).

\section{Analisis Mineral (Kalsium)}

Analisis mineral tepung ikan peperek meliputi analisis kalsium dengan menggunakan metode peniteran subtitusi.

\section{Rancangan Penelitian}

Penelitian ini menggunakan Rancangan Acak Lengkap (RAL) yang terdiri dari 3 Perlakuan yaitu Tulang (A), Kepala (B) dan Jeroan (C). Masing-masing perlakuan dilakukan empat kali ulangan, sehingga diperoleh jumlah satuan percobaan sebanyak 12 unit.

\section{Analisis Data}

Untuk mengetahui pengaruh perlakuan terhadap perameter yang akan diamati maka akan dilakukan analisis ragam (ANOVA) dan jika terdapat pengaruh nyata pada perlakuan yang diberikan maka akan dilanjutkan dengan Uji DMRT pada tingkat kepercayaan 95\% $(\alpha=0,05)$ (Steel and Torrie, 1993).

HASIL DAN PEMBAHASAN

\begin{tabular}{llll}
\hline \multicolumn{1}{c}{$\begin{array}{c}\text { Parameter } \\
\text { Pengamatan }\end{array}$} & \multicolumn{3}{c}{ Perlakuan } \\
\cline { 2 - 4 } & \multicolumn{1}{c}{ A } & \multicolumn{1}{c}{ B } \\
\hline Nilai Sensorik & & & C \\
- Kenampakan & $8,04 \pm 0,32^{\mathrm{a}}$ & $7,08 \pm 0,11^{\mathrm{b}}$ & $6,8 \pm 0,21^{\mathrm{c}}$ \\
- Bau & $8,02 \pm 0,13^{\mathrm{a}}$ & $7,22 \pm 0,17^{\mathrm{ab}}$ & $6,9 \pm 0,13^{\mathrm{c}}$ \\
- Tekstur & $8,04 \pm 0,118^{\mathrm{a}}$ & $7,32 \pm 0,11^{\mathrm{b}}$ & $6,78 \pm 0,22^{\mathrm{c}}$ \\
Nilai Proksimat & & & \\
- Protein & $27,56 \pm 0,70^{\mathrm{a}}$ & $29,0 \pm 0,26^{\mathrm{b}}$ & $31,51 \pm 1,01^{\mathrm{c}}$ \\
- Karbohidrat & $0,0260 \pm 0,002^{\mathrm{a}}$ & $0,0268 \pm 0,003^{\mathrm{ab}}$ & $0,0323 \pm 0,004^{\mathrm{bc}}$ \\
\hline
\end{tabular}




\begin{tabular}{l}
$\begin{array}{l}\text { Nilai Mineral } \\
\text { - Kalsium }\end{array} \quad 0,54 \pm, 092^{\text {bc }} \quad 0,38 \pm 0,005^{\text {ab }} \quad 0,31 \pm 0,012^{\mathrm{a}}$ \\
\hline $\begin{array}{l}\text { Keterangan : A (tulang), B (kepala), C (jeroan). Angka yang diikuti notasi huruf yang sama menunjukkan } \\
\text { perbedaan tidak nyata }\end{array}$
\end{tabular}

\section{Nilai Sensorik}

\section{Kenampakan}

Hasil uji sensori terhadap kenampakan (rupa) pada tepung ikan peperek menunjukkan nilai rerata tertinggi terdapat pada perlakuan A (tulang) dengan nilai sebesar 8,04 sedangkan nilai rerata terendah terdapat pada perlakuan $\mathrm{C}$ (jeroan) dengan nilai sebesar 6,8. Hal ini diduga dipengaruhi oleh bahan penyusun, warna tepung ikan yang dihasilkan pada perlakuan A dengan bahan penyusun tulang memiliki warna putih keabuan dibanding perlakuan B (kepala) dan perlakuan C (jeroan). Menurut Nabil (2005), menyatakan bahwa selama proses pembuatan tepung tulang, banyak bahan organik yang terhidrolisis, akibatnya warna putih keabuan tepung semakin tinggi. Nilai terendah terdapat pada perlakuan $\mathrm{C}$ (jeroan) hal ini diduga dipengaruhi oleh warna coklat yang dihasilkan produk tepung ikan. Produk tepung ikan memiliki warna coklat hal ini disebabkan oleh lemak yang terdapat dalam jeroan dapat menyebabkan oksidasi yang menghasilkan warna coklat pada tepung Nabil (2005).

\section{Bau}

Hasil uji sensori terhadap bau dari tepung ikan peperek menunjukkan nilai rerata tertinggi terdapat pada perlakuan A (tulang) dengan nilai sebesar 8,02 sedangkan nilai rerata terendah terdapat pada perlakuan $\mathrm{C}$ (jeroan) dengan nilai sebesar 6,9. Hal ini di duga karena perlakuan A (tulang) memiliki bau yang tidak begitu amis. Umumnya panelis akan menyukai bahan pangan jika mempunyai aroma khas yang tidak menyimpang dari aroma normal (Rumapar, 2015). Rendahnya nilai bau pada perlakuan $\mathrm{C}$ (jeroan) diduga dipengaruhi oleh bau amis yang terkandung dalam jeroan. Bau amis ini disebabkan oleh tingginya kadar lemak yang terkandung. Menurut Bhaskar dan Mahendrakar (2008), yang menyatakan bahwa limbah industri perikanan misalnya jeroan memiliki kandungan protein dan asam lemak tak jenuh yang tinggi.

\section{Tekstur}

Hasil uji sensori terhadap tekstur dari tepung ikan peperek menunjukkan nilai rerata tertinggi terdapat pada perlakuan A (tulang) dengan nilai rerata 8,04 sedangkan nilai rerata terendah terdapat pada perlakuan $\mathrm{C}$ (jeroan) dengan nilai rata-rata 6,78 . Hal serupa juga terlihat pada penelitian Rahman et al. (2012) tentang pembuatan tepung ikan untuk pembuatan sop ikan instant, memperlihatkan nilai tekstur pada uji sensori berkisar antara 7,43 hingga 8,43. Hal ini diduga karena tekstur pada tepung ikan terlihat halus, stabil dan merata. Hal ini sesuai dengan pernyataan Ismanadji et al. (2000) yang menyatakan bahwa pada pengolahan tepung tulang ikan tuna menunjukkan tekstur dengan butiran halus dan merata, warna coklat muda kusem dan bau seperti ikan kering. Menurut Olden, (1960) yang menyatakan bahwa tepung ikan untuk dikonsumsi manusia memiliki bentuk yang stabil, tidak berbau dan tidak berasa serta mempunyai warna yang menghampiri putih. 


\section{Nilai Proksimat}

\section{Kadar Protein}

Hasil uji proksimat terhadap kadar protein pada tepung ikan peperek menunjukkan nilai rerata tertinggi terdapat pada perlakuan C (jeroan) dengan nilai rerata 31,51 sedangkan nilai rerata terendah terdapat pada perlakuan A (tulang) dengan nilai rerata 27,56. Hal ini diduga karena tingginya kadar protein yang terdapat pada perlakuan C (jeroan) karena jeroan memiliki kandungan protein yang tinggi. Hal ini sesuai dengan pendapat Bhaskar dan Mahendrakar (2008), yang menyatakan bahwa limbah industri perikanan misalnya jeroan memiliki kandungan protein dan asam lemak tak jenuh yang tinggi. Pada penelitian nurhayati et al. (2014), kadar protein jeroan ikan yang diperoleh dalam bentuk basis kering yaitu 31,20, sedangkan kadar protein ini tidak berbeda jauh dari kadar protein tepung jeroan ikan peperek yaitu 31,45.

\section{Kadar Karbohidrat}

Hasil uji proksimat terhadap kadar karbohidrat pada tepung ikan peperek menunjukkan nilai rerata tertinggi terdapat pada perlakuan C (jeroan) dengan nilai sebesar 0,032 sedangkan nilai rerata terendah terdapat pada perlakuan A (tulang) dengan nilai sebesar 0,0260. Hal ini diduga karena kadar karbohidrat pada ikan sangat rendah karena tidak mengandung serat namun dalam bentuk glikogen serta dipengaruhi oleh kondisi ikan yang menyebabkan penurunan kadar glikogen sehingga kadar karbohidrat pada tepung ikan pada penelitian ini cukup rendah. Hal ini sesuai dengan pendapat Syahril. (2013), menyatakan bahwa kandungan karbohidrat dalam ikan sangat kecil dibandingkan zat gizi lain. Karbohidrat setelah diabsorbsi oleh sel, glukosa segera diubah menjadi energi atau disimpan dalam tubuh dalam bentuk glikogen. Menurut Okuzumi dan Fujii. (2000), yang menyatakan bahwa karbohidrat yang ada dalam produk perikanan tidak mengandung serat dan kebanyakan terdapat dalam bentuk glikogen.

\section{Kadar Kalsium}

Hasil uji mineral kadar Kalsium pada tepung ikan peperek menunjukkan nilai rerata tertinggi terdapat pada perlakuan A (tulang) dengan nilai sebesar 0,54 sedangkan nilai rerata terendah terdapat pada perlakuan $\mathrm{C}$ (jeroan) dengan nilai sebesar 0,31. Hal ini diduga karena tulang memiliki kandungan kalsium terbanyak, karena unsur utama dari tulang ikan adalah kalsium, fosfor dan karbonat. Hal ini sesuai dengan pendapat Trilaksani et al. (2006), yang menyatakan bahwa tulang ikan merupakan salah satu bentuk limbah dari industri pengolahan ikan yang memiliki kandungan kalsium terbanyak diantara bagian tubuh ikan, karena unsur utama dari tulang ikan adalah kalsium, fosfor dan karbonat. Menurut Jung et al. (2005), tulang ikan hoki (Johnius belengerii) mengandung bahan organik sekitar 30,54\% (bk) yang terdiri dari protein $28,04 \%$, lipid $1,94 \%$ dan karbohidrat $0,56 \%$, sedangkan bahan mineral anorganiknya sekitar $69,46 \%$ (bk) terutama terdiri dari $59,69 \%$ kalsium (Ca) dan $35,81 \%$ fosfor $(\mathrm{P})$ nilai ini jauh lebih tinggi jika dibandingkan dengan kandungan kalsium tepung ikan peperek yaitu $0,54 \%$.

\section{KESIMPULAN}

Berdasarkan hasil penelitian, maka dapat disimpulkan bahwa terdapat pengaruh nyata tepung ikan peperek terhadap uji organoleptik (kenampakan, bau dan tekstur), uji proksimat (kadar 
protein dan kadar karbohidrat) dan uji Mineral (kadar kalsium).

\section{DAFTAR PUSTAKA}

Arsito, Bahtiar, Ketjulan R. 2016. Distribusi Ukuran Matang Gonad Ikan Peperek (Leiognathus equulus) di Perairan Teluk Kendari Provinsi Sulawesi Tenggara

Asriyana, Raharjo MF, Djamartupal F, Batu L, Endi S, Kartamihardja. 2009. Komposisi Jenis dan Ukuran Ikan Petek (Famili Leiognathidae) di Teluk Kendari Sulawesi Tenggara, Jurnal Iktiologi Indonesia. 11(1): 11-19.

Balai Penelitian Tanah. 2005. Petunjuk Teknis Analisis Kimia Tanah, Tanaman, Air dan Pupuk. Balai Penelitian Tanah. Badan Penelitan Dan Pengembangan Pertanian. Departemen Pertanian.

Bhaskar N, Mahendrakar N. 2008. Protein hydrolisate from visceral waste protein of catla (Catla catla): optimization of hydrolysis condition for a commercial neutral protease. Journal Bioresource Technology. 99: 4105-4111.

Burgess GHO, Cutting EL, Lovern JA, Waterman JJ. 1967. Fish Handling and Processing. Chemical Publishing Company, Inc. New York. 390 halaman.

Hidayat N, Masdiana CP, Suhartini S. 2006. Mikrobiologi Industri. Yogyakarta: Universitas Gadja Mada.

Ilyas S. 1982. Teknologi Pemanfaatan Lemuru Selat Bali. Balai Penelitian Teknologi Perikanan. Jakarta.
Ismanadji I, Djazuli N, Widarto, Istihastuti $\mathrm{T}$, Herawati $\mathrm{N}$, Ismarsudi, Lasmono.2000. Laporan Perekayasaan Teknologi Pengolahan Limbah. Jakarta : Balai Bimbingan dan Pengujian Mutu Hasil Perikanan, Direktorat Jenderal Perikanan.

Jung WK, Park PJ, Byun HG, Moon SH, Kim SK. 2005. Preparation of hoki (Johniusbelengerii) bone oligophosphopeptide with a high affinity to calcium by carnivorous intestine crude proteinase. Food Chem 91: 333-340.

Murtidjo AB. 2001. Beberapa Metode Pembenihan Ikan Air Tawar. Jogjakarta: Kanisus.

Nabil M. 2005. Pemanfaatan Limbah Tulang Ikan Tuna (Thunnus sp.) Sebagai Sumber Kalsium dengan Metode Hidrolisis Protein. Institut Pertanian Bogor.

Nugroho JS. 2006. Optimalisasi Pemanfaatan Ikan Pepetek (Leiognathus sp.) Dan Ubi Jalar Putih (Ipomoeae Batatas L) Untuk Subtitusi Parsial Tepung Terigu Dalam Pembuatan Biskuit. Fakultas Perikanan Dan Ilmu Kelautan. Institu Pertanian Bogor. Bogor.

Okuzumi M, Fujii T. 2000. Nutritinonal and functional properties of squid and cuttlefish. National cooperative association of squid processor. Japan.

Olden JH. 1960. Fish flour for human consumption. Comercial fishheries review. Vol 22, no 1

Rahman MA, Saifullah M, and Islam MN. 2012. Fish powder in instant fish soup mix. J. Bangladesh Agril. Univ. 10(1): 145-148. 
Rumapar M. 2015. Fortifikasi tepung ikan (decapterus $s p$ ) pada mie basah yang menggunakan tepung sagu sebagai subtitusi tepung terigu. Majalah Biam Juli 2015. 11(1): 26-36.

Sasmito H, Andi IN, Abdullah. 2016. Pola pertumbuhan Ikan Peperek (Leiognathus equulus) di Teluk Kendari Provinsi Sulawesi Tenggara.

Steel RGD, Torrie JH. 1993. Prinsip dan Prosedur Statistika. Jakarta: Penerbit PT. Gramedia Pustaka Umum.

Syahril, Muhammad. 2013. Sifat Fisika Kimia Minyak Atsiri. Program Sarjana. Universitas Hasanudin. Makassar.

Trilaksani W, Salamah E, Nabil M. 2006. Pemanfaatan Limbah Tulang Ikan Tuna (Thunnus sp.) Sebagai Sumbr Kalsium Dengan Metode Hidrolisis Protein. Buletin Teknologi Hasil Perikanan. 9(2). 